\title{
What Are Intermediate-Severity Forest Disturbances and Why Are They Important?
}

\author{
Justin L. Hart *(D) and Jonathan S. Kleinman $(\mathbb{D}$ \\ Department of Geography, University of Alabama, Tuscaloosa, AL 35487, USA; jskleinman@crimson.ua.edu \\ * Correspondence: hart013@ua.edu; Tel.: +1-205-348-1673; Fax: +1-205-348-2278
}

Received: 16 July 2018; Accepted: 17 September 2018; Published: 19 September 2018

\begin{abstract}
The classification of discrete forest disturbance events is usually based on the spatial extent, magnitude, and frequency of the disturbance. Based on these characteristics, disturbances are placed into one of three broad categories, gap-scale, intermediate-severity, or catastrophic disturbance, along the disturbance classification gradient. We contend that our understanding of disturbance processes near the endpoints of the disturbance classification gradient far exceeds that of intermediate-severity events. We hypothesize that intermediate-severity disturbances are more common, and that they are more important drivers of forest ecosystem change than is commonly recognized. Here, we provide a review of intermediate-severity disturbances that includes proposed criteria for categorizing disturbances on the classification gradient. We propose that the canopy opening diameter to height ratio $(\mathrm{D}: \mathrm{H})$ be used to delineate gap-scale from intermediate-severity events and that the threshold between intermediate and catastrophic events be based on the influence of residual trees on the composition of the regeneration layer. We also provide examples of intermediate-severity disturbance agents, return intervals for these events, and recommendations for incorporating natural intermediate-severity disturbance patterns in silvicultural systems.
\end{abstract}

Keywords: disturbance; moderate severity; stand development; structure; succession

\section{Introduction}

All forest stands are in a state of recovery from prior disturbance [1]. Disturbances modify species composition, the arrangement of biomass and tree ages, and ecosystem functions [2,3]. These events impart informational and material legacies that may be short-lived or perpetual [4]. Disturbances may impact neighborhoods within stands, entire stands, or collections of stands to alter forest and even landscape-level vegetation patterns [5]. Species' responses to natural disturbances have long been used to guide silvicultural systems. In the natural disturbance ecology literature, canopy disturbances are typically classified in the context of the stand by spatial extent, magnitude, and return interval and placed along the disturbance classification gradient into one of three broad categories: Gap-scale disturbances, intermediate-severity disturbances, or catastrophic disturbances [6]. Gap-scale disturbances are caused by the removal of a single canopy tree, a small cluster of trees, or even a large branch from a canopy dominant individual. These disturbances modify microscale biophysical conditions and occur frequently in stands [7-9]. Catastrophic disturbances result from the removal of most all overstory vegetation, serve to regenerate stands, and occur relatively infrequently [10-12]. Between these two endpoints of the disturbance classification gradient exist events classed as intermediate severity.

The scientific understanding of natural gap-scale and catastrophic forest disturbances exceeds that of intermediate-severity events [13-15]. Although many studies have been conducted to document the impacts of intermediate-severity disturbances in forest ecosystems, few have explicitly defined the canopy disturbance events analyzed along the disturbance classification gradient or placed the 
studies in the context of intermediate-severity disturbance in general. These studies have made important contributions to their respective subfields, such as fire disturbance or wind disturbance, but a synthesis of intermediate-severity disturbance events is lacking. A confounding factor is that canopy disturbance severity can be measured from a wide range of ecosystem response variables and this complicates making broad generalizations of intermediate-severity disturbances that result from diverse disturbance agents [16]. However, the most basic response variable in forest ecosystems is basal area removed (i.e., tree mortality) [5,17]. By focusing on basal area as the criterion for disturbance severity classification, disturbance severity and disturbance scale (i.e., spatial extent) are directly proportional. A forest disturbance event that removes one canopy tree or a small cluster of individuals would represent a relatively small reduction in basal area, and be small in spatial extent. Conversely, a forest disturbance that removes most all overstory trees in a stand would represent a significant reduction in basal area, and would also occur over a greater extent of the stand. Tree mortality is the common thread in all intermediate-severity disturbance studies, and by restricting our focus to tree mortality, we can make broader generalizations about intermediate-severity disturbance patterns and processes. Our goal is to synthesize information from the disturbance ecology literature to advance our understanding of intermediate-severity disturbance as a category of disturbance. Intermediate-severity disturbances may produce a wide range of residual stand structures, create multi-aged stands, alter successional pathways, and have long lasting legacies. We speculate that intermediate-severity forest disturbances are more common and play more important roles in shaping forest ecosystems than is often recognized. We hope our review of intermediate-severity disturbances will result in a greater understanding of these events, which will ultimately aid forest management planning.

\section{What Are Intermediate-Severity Disturbances?}

A central, but as of yet unanswered, question is at what point does a canopy disturbance event cross the threshold from gap scale to intermediate severity or likewise, from intermediate severity to catastrophic [18]. In theory, all forest disturbances that exceed the definition of a canopy gap, but are not stand replacing (i.e., catastrophic) would be considered intermediate-severity events [19]. The endpoints on the disturbance classification gradient represent a large range as canopy gaps usually involve the death of only one or a small group of trees and catastrophic events involve the removal of most all overstory stems [6,8]. Thus, the majority of the disturbance classification gradient would actually be within the intermediate-severity disturbance category (Figure 1).

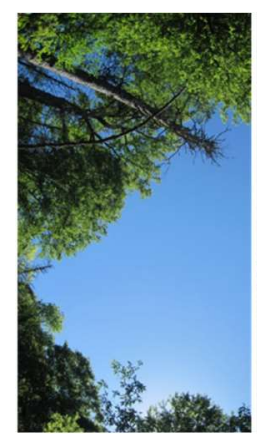

Gap scale

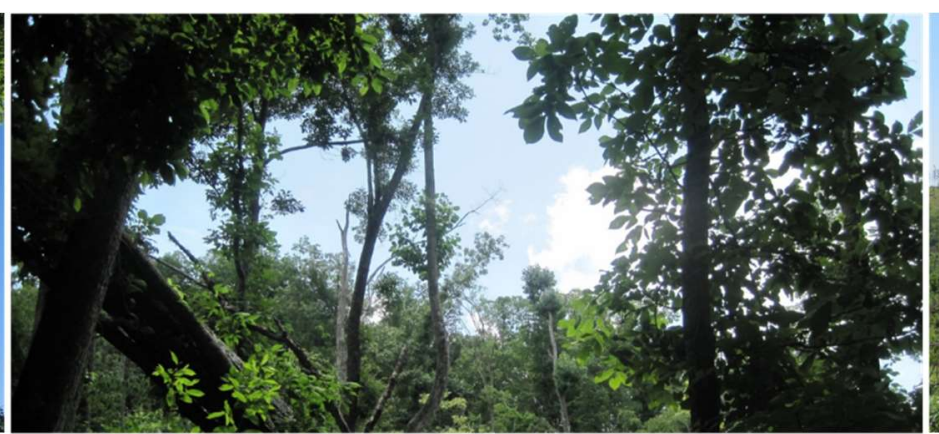

Intermediate severity

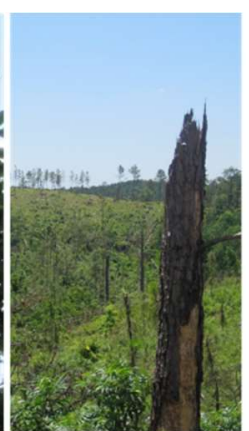

Catastrophic

Disturbance classification gradient

Figure 1. Forest disturbance classification gradient based on spatial extent, magnitude, and frequency of discrete disturbance events (adapted from Hart [9]). Basal area removed increases from left to right.

\subsection{Gap to Intermediate Disturbances}

Although it is straightforward to assume the void created by the death of a single canopy tree would be classified as gap-scale disturbance, this classification becomes less clear as the 
number of canopy trees removed increases. The most common approach has been to set upper size limits for the classification of canopy gaps to separate gaps from intermediate-severity events. For example, Schliemann and Bockheim [20] suggested that maximum gap size should be $1000 \mathrm{~m}^{2}$. Similarly, Yamamoto [8] stated that canopy gaps were typically less than $1000 \mathrm{~m}^{2}$ in extent. However, some researchers have categorized disturbances beyond $1000 \mathrm{~m}^{2}$ as gap-scale events (e.g., References [21-24]). In contrast, many studies have reported maximum gap sizes of less than $500 \mathrm{~m}^{2}$ (e.g., References [25-29]). Because of variability in forest structure and species composition, we propose that it is best to use a metric that includes height of surrounding vegetation rather than a static size threshold to delineate gap-scale from intermediate-severity disturbances. Although it would be simple to state that all events larger than a pre-determined threshold would be too large to be classed as canopy gaps, disturbance extent should be scaled in relation to the size of the organisms that dominate the ecosystem (i.e., the trees). We propose that gaps are context specific and upper size thresholds vary by stand characteristics, primarily by tree density and tree height.

The diameter of the gap (often an average of the length, which is the longest distance from gap edge to gap edge, and the width, which is the longest distance perpendicular to the length) in relation to the mean height of canopy trees surrounding the gap (D:H), has been reported by some authors; and we contend this is the best criterion to classify canopy disturbances that fall near the gap scale-intermediate severity boundary. At present, there is no universally accepted D:H threshold to separate gap-scale from intermediate-severity canopy disturbance events. Reported D:H ratios vary by forest type. For example, Richards and Hart [30] reported mean D:H of 0.5 in mixed Quercus stands in the southeastern USA. Similar D:H values were reported by Kneeshaw and Bergeron [31] in boreal stands in Quebec, Canada and by Spies et al. [32] in Pseudotsuga menziesii (Mirb.) Franco-Tsuga heterophylla (Raf.) Sarg. stands in Oregon and Washington, USA. Runkle [7], a pioneer of canopy gap research in temperate forests, stated that D:H values of canopy gaps in temperate hardwood stands were typically <1.0. We suggest that $\mathrm{D}: \mathrm{H}$ values are needed from more forest types before a universal D:H value to delineate gap-scale from intermediate-severity disturbance can be established. Nonetheless, we suggest that D:H of 2.0 serve as a starting point and stress that this value may be adjusted based on forest type and the range of values reported from canopy disturbances [33,34]. This value corresponds to the threshold between medium and large gaps proposed by Zhu et al. [18]. Zhu et al. [18] analyzed the impact of canopy trees surrounding gaps on growth of shade intolerant tree species within gaps. Specifically, they analyzed shadow length of gap perimeter trees at local noon during the growing season and photosynthetically active radiation in the gap and proposed that a D:H of 2.0 separate medium from large canopy gaps.

It is imperative to note that gap size or even D:H of canopy disturbances cannot be used alone to classify a forest disturbance event. Discrete disturbance events are classified in the context of the forest stand. Therefore, a high frequency of relatively small canopy gaps may actually constitute an intermediate-severity disturbance, if gap creation exceeds the background gap formation rate. For example, in mixed hardwood stands of the eastern USA, the canopy gap formation rate is typically $0.5 \%-2.0 \%$ per year $[7,22]$. Thus, the average time between natural canopy disturbances for a given location within a stand is 50-200 years [7]. The creation of even small canopy gaps above the background formation rate would, at the stand scale, be an intermediate-severity disturbance event.

\subsection{Intermediate to Catastrophic Disturbances}

Literature concerning the threshold separating intermediate-severity and catastrophic disturbances is not as well developed as that for upper limits of canopy gap size. By definition, catastrophic disturbances remove most all overstory vegetation. At what point is residual tree density or residual basal area high enough that the event is not catastrophic, but actually intermediate in severity? We suggest this threshold should correspond to the point when residual trees have an impact on biophysical conditions such that regeneration patterns are altered from what would occur following the removal of the entire overstory. After a catastrophic disturbance, light intensity, surface 
temperature, evaporation rates, and light quality increase. As the number of residual trees or amount of residual basal area (corresponding to residual overstory) increases, the change in light intensity, evapotranspiration rates, and diurnal temperature variation is lessened [34]. Our proposed criterion is consistent with the seed tree regeneration method. The seed tree method is an even aged regeneration method that removes most mature trees in one entry, similar to a clearcut. The difference is that some residual, mature trees are left singly or in groups throughout the harvested area to supply seed for natural regeneration, but the residual cover of seed trees does not modify the physical environment more than what would have been created by a clearcut [35]. When residual trees are sufficient in density or basal area to impact conditions in the regeneration layer, the entry would not be categorized as a seed tree, but rather as a shelterwood. The number and spatial configuration of the seed trees varies by forest type and site conditions. However, most seed tree cutting retains 5-30 mature trees ha ${ }^{-1}$ [34]. In western North America, as few as 7 seed trees ha ${ }^{-1}$ are often retained for Larix occidentalis Nutt. and as many as 20 for Pseudotsuga menziesii [36,37]. In Pinus echinata Mill. stands in the southeastern USA, as many as 124 seeds trees ha ${ }^{-1}$ may be retained when diameter at breast height averages ca. $25 \mathrm{~cm}$ (ca. $6 \mathrm{~m}^{2}$ basal area ha ${ }^{-1}$ ) and in Pinus taeda L. and Pinus elliottii Engelm. stands ca. 74 seed trees may be retained [38]. We propose this silvicultural distinction, which is based on the regeneration requirements of desired species, is also appropriate for the classification of natural canopy disturbances, because it is based on the influence of tree mortality on successional and developmental pathways.

Therefore, we propose that the boundary between gap-scale and intermediate-severity disturbances be canopy openings with a D:H of $>2.0$ and at the stand scale to be less than the background mortality rate. We note that light is not the only factor that influences gap dynamics [39-41], but D:H is appropriate for other noted factors of gap-scale processes. D:H is increasingly used to guide silvicultural systems to achieve desired stand conditions [34,42]. Therefore, using canopy opening D:H may help unify disturbance categorization with silviculture terminology and practice. We propose that the boundary between intermediate-severity and catastrophic events be set to the point at which residual stems influence regeneration patterns. This criterion is also consistent with silvicultural classification. We propose these as starting points and hope that our suggestions will be modified as more quantitative data become available.

\section{What Causes Intermediate-Severity Disturbances?}

Intermediate-severity disturbances are caused by a range of biotic and abiotic disturbance agents (Table 1). We acknowledge that a relatively large body of literature exists for most specific agents. However, we suspect that most in the disturbance ecology community are well versed in the literature related to the disturbance agents they study, but may be relatively unaware of other agents that also result in intermediate-severity disturbances. Our goal is to highlight some of these disturbance agents, and provide a framework to synthesize information from different disturbance processes to advance our understanding of intermediate-severity events. Natural biotic disturbance agents that may result in intermediate-severity disturbances include insect outbreaks and pathogens [43]. Castanea dentata (Marshall) Borkh. was abundant throughout the eastern USA in the early 1900s. The species was a common canopy tree, and in some stands represented over $40 \%$ of the basal area [44]. By the mid-1900s, the species was functionally extinct, because of the introduction and spread of Cryphonectria parasitica (Murrill) Barr [45]. The loss of C. dentata in a short period from stands where it was dominant resulted in an intermediate-severity disturbance event and is evident today in species composition and stand and age structure of stands where the species once occurred [46,47]. A similar story is currently unfolding with Tsuga Canadensis (L.) Carrière. This species once spanned from southern Quebec and Ontario, Canada southward along the Appalachian Highlands into Georgia and Alabama, USA. The species was dominant especially in riparian zones and protected coves and could form almost pure stands. Tsuga canadesis is currently facing an extinction threat by Adelges tsugae Annand. The species has already been lost from stands throughout the core of its range and the level of mortality in many of these stands constitutes intermediate-severity disturbance. Periodic Dendroctonus ponderosae 
Hopkins outbreaks have maintained stand structural complexity in Pinus contorta Douglas ex Loudon stands $[48,49]$. Other examples of pathogen and pest-induced intermediate-severity disturbances include Ceratocystis platani Engelbrecht \& Harrington [50], Choristoneura freemani Razowski [51], Agrilus planipennis Fairmaire [52,53], and Cryptococcus fagisuga Lindinger-Nectria coccinea var. faginata M.L. Lohman, A.M.J. Watson \& Ayers [54].

Table 1. Examples of studies that have investigated intermediate-severity forest disturbances from a variety of disturbance agents.

\begin{tabular}{|c|c|c|c|}
\hline Disturbance Agent & Location & Forest Type & Citation \\
\hline Drought & Arizona, USA & $\begin{array}{l}\text { Pinus edulis Engelm.-Juniperus } \\
\text { monosperma (Engelm.) Sarg. }\end{array}$ & Mueller et al., 2005 [55] \\
\hline Drought & North Carolina, USA & Mixed Quercus & Elliot and Swank 1994 [56] \\
\hline Flood & Tochigi, Japan & Quercus mongolica Fisch. ex Ledeb. & Sakai et al., 1999 [58] \\
\hline Ice storm & Connecticut, USA & Quercus rubra L. & Covey et al., 2015 [59] \\
\hline Ice storm & Missouri, USA & Quercus alba L.-Quercus rubra & Rebertus et al., 1997 [60] \\
\hline Ice storm & Virginia, USA & Mixed Quercus & Whitney and Johnson 1984 [63] \\
\hline Insect outbreak & Alberta, Canada & Pinus contorta & McIntosh and Macdonald 2013 [64] \\
\hline Insect outbreak & British Columbia, Canada & Pinus contorta & Axelson et al., $2010[48]$ \\
\hline Insect outbreak & Pennsylvania, USA & Mixed Quercus & Fajvan and Wood 1996 [65] \\
\hline Insect outbreak & Wyoming, USA & Pinus contorta & Kayes and Tinker 2012 [66] \\
\hline Landslide & Miyagi, Japan & Fagus crenata Blume & Seiwa et al., 2013 [67] \\
\hline Pathogen & Hawaii, USA & Metrosideros polymorpha Gaudich. & Mortenson et al., 2016 [72] \\
\hline Pathogen & North Carolina, USA & Mixed Quercus & Keever 1953 [44] \\
\hline Wind event & Alabama, USA & Mixed Quercus & Cox et al., 2016 [73] \\
\hline Wind event & Illinois, USA & Mixed Quercus & Holzmueller et al., 2012 [74] \\
\hline Wind event & Jeju-do, South Korea & Quercus mongolica & Altman et al., 2013 [75] \\
\hline Wind event & Oklahoma, USA & $\begin{array}{l}\text { Quercus marilandica Münchh.-Quercus } \\
\text { stellata Wangenh. }\end{array}$ & Myster and Malahy 2010 [76] \\
\hline Wind event & Slovenia & Fagus sylvatica L.-Abies alba Mill. & Nagel and Diaci 2006 [77] \\
\hline Wind event & Wisconsin, USA & Acer-Tsuga-Betula & Hanson and Lorimer 2007 [14] \\
\hline
\end{tabular}

Natural abiotic disturbance agents that cause intermediate-severity disturbance include low intensity tornadoes, floods, ice storms, mixed-severity fires, and landslides. Low intensity tornadoes and other strong wind events, such as derechos, often remove canopy trees $[73,78]$ and result in intermediate levels of damage [14,15,19,79-81]. Flooding may result in intermediate-severity disturbances $[57,58]$ as species that occupy floodplains vary in their tolerance of submersion, and prolonged inundation may result in mortality of the relatively more flood sensitive species [82]. Ice or glaze storms may also result in intermediate-severity disturbance [60,62,63]. Ice loading often removes canopy trees and patterns of mortality may be caused by topographic factors or species-specific characteristics [83]. A wide range of structures may result from mixed-severity fires (more importantly from the mixed-severity fire regime). Individual mixed-severity fires typically include patches that sustained high, moderate, and low severity fire, as well as patches that went unburned [84]. This pattern of mortality across the landscape may foster the development of biologically diverse communities and complex stand and age structures $[48,85,86]$. Landslides, which are common in some regions, can also result in intermediate-severity disturbance [68,87]. For example, the remnants of Hurricane Camille in 1969 triggered 5377 documented landslides (mainly in the form of debris flows) in the Appalachian Highlands of Virginia and West Virginia [88].

In some cases, intermediate-severity disturbances may interact with subsequent disturbances to produce compound effects that delay or alter forest recovery trajectories [89]. In a Rocky Mountain Pseudotsuga menziesii forest, in Wyoming, USA, Harvey et al. [90] attributed reduced post-fire regeneration density to a Dendroctonus pseudotsugae outbreak, 4-13 years before the fire. By preferentially killing mature, cone-producing trees throughout the forest, the intermediate-severity D. pseudotsugae outbreak reduced the available seed source for post-fire regeneration, thereby negatively 
impacting forest resilience. In a Pinus contorta forest in central Oregon, USA, intermediate-severity Arceuthobium americanum Nutt. ex Engelm. infection was associated with delayed forest development 21-28 years after a Dendroctonus ponderosae outbreak [91]. Although pre-outbreak A. americanum severity was not quantified, it is likely that by killing canopy trees, the $D$. ponderosae outbreak facilitated the spread of $A$. americanum, which restricted residual trees from recruiting to higher forest strata. Thus, multiple interacting disturbances may impact forest succession and development in ways that are distinct from isolated disturbance events, and it is important to consider the impacts of intermediate-severity disturbances in the context of other disturbances.

Spatial patterns of mortality and residual trees of intermediate-severity disturbances can typically be classified as uniform, patch, or linear [6,92] (Figure 2). Derechos and ice storms may remove the largest and most dominant canopy trees throughout a stand resulting in a uniform pattern [83,93]. Species-specific mortality agents could result in uniform or patch patterns depending on the spatial distribution of the susceptible species. Tornadoes and floods often result in linear patterns of mortality through a stand corresponding to the storm track or the stream corridor [45]. These events may result in complete mortality of overstory individuals so that they are catastrophic at local scales, but intermediate in severity at the stand scale. The spatial patterns of residual trees may influence the developmental and successional pathways following intermediate-severity disturbance [92].

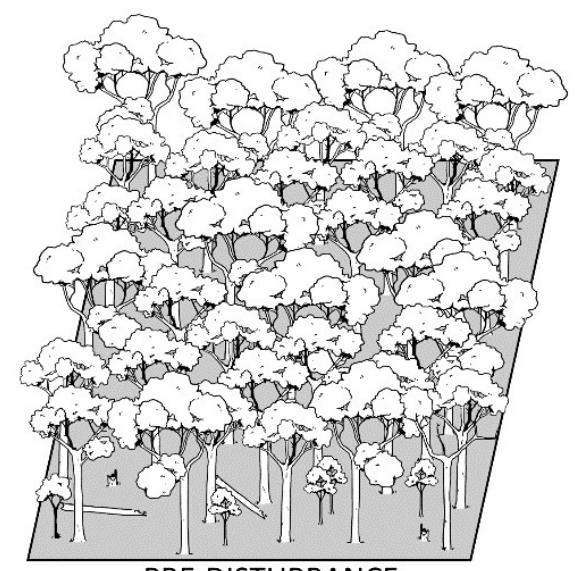

PRE-DISTURBANCE

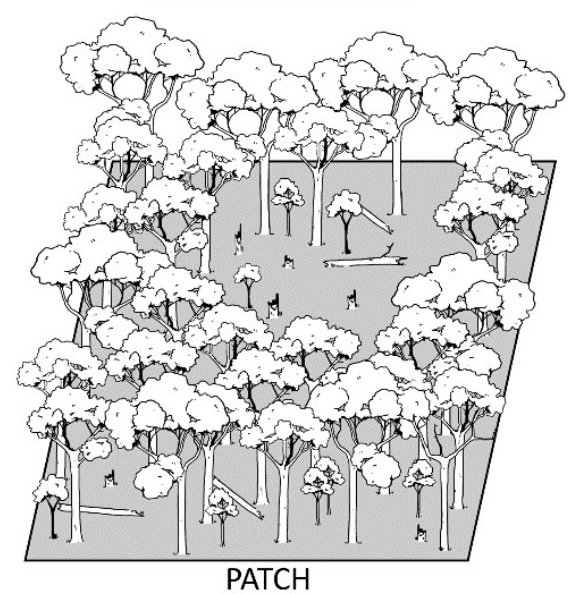

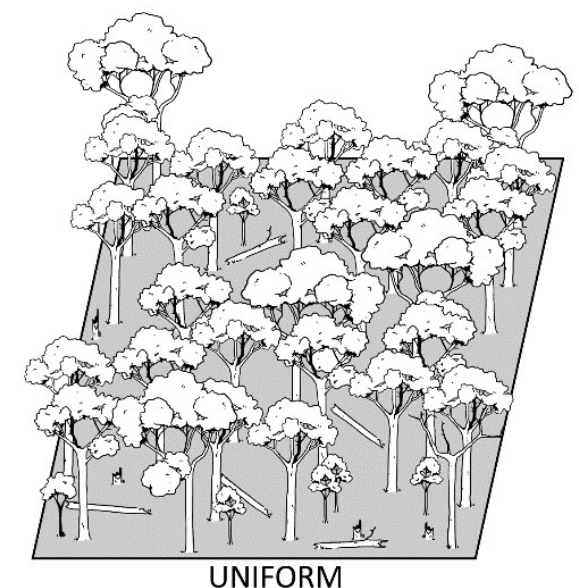

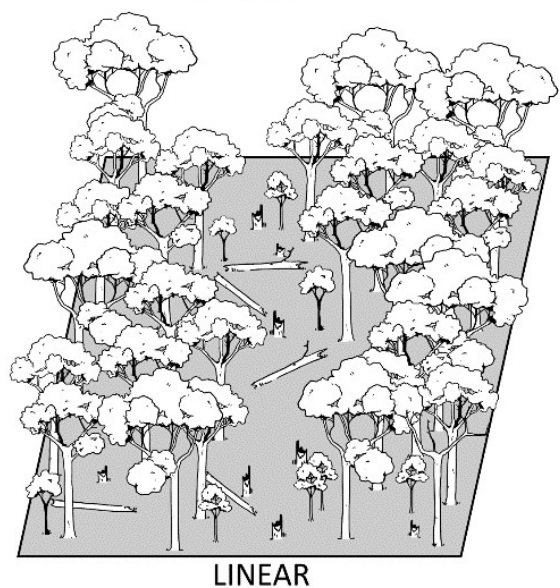

Figure 2. Spatial patterns of mortality and residual trees after intermediate-severity disturbance. The pre-disturbance condition represents a mature, deciduous broadleaf dominated stand prior to intermediate-severity disturbance. In the uniform pattern, canopy trees were removed relatively evenly throughout. The patch pattern shows clustered mortality and the linear pattern shows stems removed in a strip. In each disturbance pattern depicted, seven canopy trees (ca. 25\% reduction in canopy tree density from the pre-disturbance depiction) were removed. 


\section{How Frequent Are Intermediate-Severity Disturbances?}

An important component of the forest disturbance regime is the return interval of disturbances by severity. Quantification of the disturbance regime is often based on retrospective investigations. A common method to reconstruct and classify forest disturbance regimes is through the use of tree-ring analysis. Disturbance history reconstructions using tree-ring records and forest inventory data (especially tree age data) have been conducted in stands across a wide range of forest types. Although variability exists by forest type and region, studies generally show that stands are impacted by (i.e., have a history of) intermediate-severity disturbances at intervals shorter than the lifespans of dominant species. In fact, in many forest types, more than one intermediate-severity disturbance is likely to occur during the lifespan of the dominant trees. In Quercus stands of the eastern USA for example, the return interval of intermediate-severity disturbance events based on tree-ring records has been found to range from 20-50 years [94-100]. An intermediate-severity disturbance return interval of ca. 50 years was reported from a 100 ha plot in a Picea abies stand in Slovakia [101] and ca. 65 years from a 20 ha plot in a P. abies stand in the Czech Republic [102]. Intermediate-severity disturbance return intervals of 20-30 years [103], 20-80 years [104], and 40 years [105] have been reported for Fagus sylvatica dominated stands in Austria, Slovenia, and the Czech Republic, respectively. In a Pinus strobus L-Tsuga canadensis stand in Massachusetts, USA, an intermediate-severity disturbance return interval of ca. 40 years was reported by Abrams et al. [106]. Axelson et al. [107] found the mean return interval of Dendroctonus ponderosae outbreaks to be 36 years across three Pinus contorta stands in British Columbia, Canada. Similarly, Fraver et al. [108] and Boulanger et al. [109] reported return intervals of Choristoneura fumiferana Clemens outbreaks to be 67 years in Maine, USA and ca. 40 years in Quebec, Canada, respectively. In seasonal dry evergreen stands in Thailand, Baker et al. [110] documented return intervals of intermediate-severity disturbance of 20-60 years.

These tree-ring based disturbance history reconstructions and plot data demonstrate that intermediate-severity disturbances are relatively common. Based on the return intervals that have been reported from these retrospective studies, most forest stands will experience at least one intermediate-severity disturbance between stand initiation and a catastrophic disturbance event. Indeed, it might be that most stands will actually experience two or more such events. We hypothesize that intermediate-severity forest disturbance events are more common than is often recognized, and their influence as a driver of species composition, stand structure, and ecosystem function is underappreciated.

\section{How May These Events Influence Our Management?}

Forest managers are increasingly tasked with developing plans to increase native forest diversity, enhance structural complexity, and promote ecosystem resilience [111]. Silvicultural systems that are patterned after natural disturbance process may be utilized to achieve these goals $[112,113]$. A deeper appreciation and understanding of intermediate-severity disturbances and the impacts these events have on species composition and stand structure, should aid in development of natural disturbance-based silvicultural systems. Increasingly, forest ecosystems are undergoing changes in species composition, structure, and function as a result of climate change, disturbance regime alteration, nitrogen deposition, fragmentation, invasive species, and other anthropogenic pressures, as well as the interactions of these factors [114-116]. Accordingly, ecological resilience has become a major focus of forest management, science, and policy [117-119]. A mechanistic understanding of intermediate-severity disturbances as drivers of forest ecosystem change is essential for the development of systems that are patterned after natural disturbance processes to meet management goals. For example, we may develop a silvicultural entry that approximates the spatial extent and spatial configuration of a natural intermediate-severity disturbance event. In the silvicultural system, time between entries may be based on the return interval of intermediate-severity disturbances in that forest type and region. Intermediate-severity disturbances result in a wide range of stand structures 
and alter developmental pathways [15,92,120,121], and thus, provide wide flexibility to forest managers for incorporation into management plans.

Intermediate-severity disturbances typically increase stand-level structural complexity through coarse woody debris inputs, creation of canopy voids, alteration of the seedbed, and changes in the light regime $[14,15,73,80,121,122]$. Importantly, intermediate-severity disturbances often result in multi-aged stands [123]. O'Hara and Ramage [124] argued that multiple age classes in a stand provide different levels of adaptations to stresses that enhances resiliency in multi-aged stands. Multi-aged silvicultural systems, including those patterned after natural intermediate-severity disturbance, should be part of our efforts to increase resistance and resilience in forest ecosystems to future, including novel, stressors $[123,125]$.

Silvicultural systems that approximate the impacts of natural intermediate-severity disturbance are being used in some forest types. For example, in the northeastern USA, irregular shelterwoods have been implemented to increase structural heterogeneity [126], such as may be caused by infrequent windstorms in the region [127]. One variant of the irregular shelterwood system is the irregular group shelterwood with reserves. This system uses shelterwood regeneration in patches within the stand, rather than uniformly, and retains reserve trees in the openings after they are regenerated [126]. In these systems, structure varies spatially through the treated stands. In the Pacific Northwest region of North America, retention systems that maintain sufficient canopy coverage to have forest or residual tree influences over the majority of the harvested area, and retain live and dead trees of varying sizes and canopy classes are becoming increasingly popular [128-130]. Both group and dispersed retention may be analogous to the impacts of natural intermediate-severity disturbances.

We understand that silvicultural systems that mimic the effects of intermediate-severity disturbance are not a panacea and not appropriate in all forest management scenarios. However, we encourage forest managers to consider intermediate-severity disturbances in their management plans and long-range forecasts. For most forest types and in most regions, intermediate-severity disturbances will occur in the life of a stand. These events should be anticipated so that the response can be more organized, more efficient, and less reactive [131]. Such anticipation will become increasingly important as disturbance regimes shift in accord with changing climates and other anthropogenic forces. Some decisions, such as salvage harvesting, must often be made quickly after intermediate-severity disturbance and anticipating these events would greatly aid the ability of managers to make sound decisions for the long-term sustainability of impacted forest ecosystems.

\section{Conclusions}

Intermediate-severity disturbances are those that are greater in extent than gap-scale disturbances and more localized than stand replacing events. Therefore, intermediate-severity disturbances represent disproportionate space along the disturbance classification gradient. We contend the best approach to delineate gap-scale from intermediate-severity events is to use the canopy opening $\mathrm{D}: \mathrm{H}$, and we recommend a D:H of 2.0 as a starting point for this threshold, while acknowledging this value may be adjusted by forest type and as new information becomes available. We recommend that the division between intermediate-severity events and catastrophic events, should be the point when residual tree density or basal area influences the regeneration layer by altering abiotic site conditions differently from what would occur after complete, or near complete, overstory removal. A variety of agents may result in intermediate disturbance and importantly, interactions of different disturbance agents (e.g., insect outbreaks and fire) may result in intermediate levels of forest disturbance [107]. The return intervals of intermediate-severity disturbance vary by forest type and region, but disturbance history reconstructions demonstrate that these events occur at intervals of 20 to 80 years $[104,110]$. Therefore, we suggest that most stands will experience an intermediate-severity event between stand initiation and a stand replacing disturbance. We speculate that intermediate-severity disturbances are more common and more important drivers of forest ecosystem change than is typically recognized and we call for more research into intermediate-severity 
disturbance, especially with regard to the impacts of these events on successional and developmental pathways [92]. Intermediate-severity disturbance patterns may be incorporated into silvicultural systems, and this may become more important as management goals increasingly include promotion of intra-stand heterogeneity [111,129].

Funding: Support was provided by the University of Alabama.

Acknowledgments: We thank the anonymous reviewers for helpful comments.

Conflicts of Interest: The authors declare no conflict of interest.

\section{References}

1. White, P.S.; Jentsch, A. The search for generality in studies of disturbance and ecosystem dynamics. Prog. Bot. 2001, 62, 399-450.

2. Amario, B.D.; Barr, A.G.; Barr, J.G.; Black, T.A.; Bracho, R.; Brown, M.; Chen, J.; Clark, K.L.; Davis, K.J.; Desai, A.R.; et al. Ecosystem carbon dioxide fluxes after disturbance in forests of North America. J. Geophys. Res. 2010, 115, G00K02. [CrossRef]

3. Goetz, S.J.; Bond-Lamberty, B.; Law, B.E.; Hicke, J.A.; Huang, C. Observations and assessment of forest carbon dynamics following disturbance in North America. J. Geophys. Res. 2012, 117, G02022. [CrossRef]

4. Johnstone, J.F.; Allen, C.D.; Franklin, J.F.; Frelich, L.E.; Harvey, B.J.; Higuera, P.E.; Mack, M.C.; Meentemeyer, R.K.; Metz, M.R.; Perry, G.L.W.; et al. Changing disturbance regimes, ecological memory, and forest resilience. Front. Ecol. Environ. 2016, 14, 369-378. [CrossRef]

5. White, P.S.; Pickett, S.T.A. Natural disturbance and patch dynamics: An introduction. In The Ecology of Natural Disturbance and Patch Dynamics; Pickett, S.T.A., White, P.S., Eds.; Academic Press: San Diego, CA, USA, 1985; pp. 3-13.

6. Oliver, C.D.; Larson, B.C. Forest Stand Dynamics; Wiley: New York, NY, USA, 1996.

7. Runkle, J.R. Disturbance regimes in temperate forests. In The Ecology of Natural Disturbance and Patch Dynamics; Pickett, S.T.A., White, P.S., Eds.; Academic Press: New York, NY, USA, 1985; pp. 17-33.

8. Yomamoto, S. Forest gap dynamics and tree regeneration. J. For. Res. 2000, 5, 223-229. [CrossRef]

9. Hart, J.L. Gap-scale disturbances in central hardwood forests with implications for management. In Natural Disturbances and Historic Range of Variation: Type, Frequency, Severity, and Post-Disturbance Structure in Central Hardwood Forests USA; Greenberg, C.H., Collins, B.S., Eds.; Springer International Publishing: Cham, Switzerland, 2016; pp. 33-47.

10. Foster, D.R.; Knight, D.H.; Franklin, J.F. Landscape patterns and legacies resulting from large, infrequent forest disturbances. Ecosystems 1998, 1, 497-510. [CrossRef]

11. Turner, M.G.; Dale, V.H. Comparing large, infrequent disturbances: What have we learned? Ecosystems 1998, 1, 493-496. [CrossRef]

12. Lorimer, C.G. Historical and ecological roles of disturbance in eastern North American forests: 9000 years of change. Wildl. Soc. Bull. 2001, 29, 425-439.

13. Seymour, R.S.; White, A.S.; deMaynadier, P.G. Natural disturbance regimes in northeastern North America-Evaluating silvicultural systems using natural scales and frequencies. For. Ecol. Manag. 2002, 155, 357-367. [CrossRef]

14. Hanson, J.J.; Lorimer, C.G. Forest structure and light regimes following moderate wind storms: Implications for multi-cohort management. Ecol. Appl. 2007, 17, 1325-1340. [CrossRef] [PubMed]

15. White, S.D.; Hart, J.L.; Schweitzer, C.J.; Dey, D.C. Altered structural development and accelerated succession from intermediate-scale wind disturbance in Quercus stands on the Cumberland Plateau, USA. For. Ecol. Manag. 2015, 336, 52-64. [CrossRef]

16. Keeley, J.E. Fire intensity, fire severity and burn severity: A brief review and suggested usage. Int. J. Wildland Fire 2009, 18, 116-126. [CrossRef]

17. Turner, M.G. Disturbance and landscape dynamics in a changing world. Ecology 2010, 91, $2833-2849$. [CrossRef] [PubMed]

18. Zhu, J.; Zhang, G.; Wang, G.G.; Yan, Q.; Lu, D.; Li, X.; Zheng, X. On the size of forest gaps: Can their lower and upper limits be objectively quantified? Agric. For. Meteorol. 2015, 213, 64-76. [CrossRef] 
19. Cowden, M.M.; Hart, J.L.; Schweitzer, C.J.; Dey, D.C. Effects of intermediate-scale wind disturbance on composition, structure, and succession in Quercus stands: Implications for natural disturbance-based silviculture. For. Ecol. Manag. 2014, 330, 240-251. [CrossRef]

20. Schliemann, S.A.; Bockheim, J. Methods for studying tree-fall gaps: A review. For. Ecol. Manag. 2011, 261, 1143-1151. [CrossRef]

21. Barden, L.S. Forest development in canopy gaps of a diverse hardwood forest of the southern Appalachian Mountains. Oikos 1981, 37, 205-209. [CrossRef]

22. Runkle, J.R. Patterns of disturbance in some old-growth mesic forests of the eastern North America. Ecology 1982, 63, 1533-1546. [CrossRef]

23. Coates, K.D. Tree recruitment in gaps of various sizes, clearcuts, and undisturbed mixed forest of interior British Columbia, Canada. For. Ecol. Manag. 2002, 155, 387-398. [CrossRef]

24. Gagnon, J.L.; Jokela, E.J.; Moser, W.K.; Huber, D.A. Characteristics of gaps and natural regeneration in mature longleaf pine flatwoods ecosystems. For. Ecol. Manag. 2004, 187, 373-380. [CrossRef]

25. Hubbell, S.P.; Foster, R.B.; O’Brien, S.T.; Harms, K.E.; Condit, R.; Wechsler, B.; Wright, S.J.; Loo de Lao, S. Light-gap disturbances, recruitment limitation, and tree diversity in a neotropical forest. Science 1999, 283, 554-557. [CrossRef] [PubMed]

26. Rentch, J.S.; Fajvan, M.A.; Hicks, R.R., Jr. Oak establishment and canopy accession strategies in five old-growth stands in the Central Hardwood forest region. For. Ecol. Manag. 2003, 184, 285-297. [CrossRef]

27. Hart, J.L.; Grissino-Mayer, H.D. Gap-scale disturbance processes in secondary hardwood stands on the Cumberland Plateau, Tennessee, USA. Plant Ecol. 2009, 201, 131-146. [CrossRef]

28. Curzon, M.T.; Keeton, W.S. Spatial characteristics of canopy disturbance in riparian old-growth hemlock-northern hardwood forests, Adirondack Mountains, New York, USA. Can. J. For. Res. 2010, 40, 13-25. [CrossRef]

29. Rentch, J.S.; Schuler, T.M.; Nowacki, G.W.; Beane, N.R.; Ford, W.M. Canopy gap dynamics of second-growth red spruce-northern hardwood stands in West Virginia. For. Ecol. Manag. 2010, 260, 1921-1929. [CrossRef]

30. Richards, J.D.; Hart, J.L. Canopy gap dynamics and development patterns in secondary Quercus stands on the Cumberland Plateau, Alabama, USA. For. Ecol. Manag. 2011, 262, 2229-2239. [CrossRef]

31. Kneeshaw, D.D.; Bergeron, Y. Canopy gap characteristics and tree replacement in the southeastern boreal forest. Ecology 1998, 79, 783-794. [CrossRef]

32. Spies, T.A.; Franklin, J.F.; Klopsch, M. Canopy gaps in Douglas-fir forests of the Cascade Mountains. Can. J. For. Res. 1990, 20, 649-658. [CrossRef]

33. Malcolm, D.C.; Mason, W.L.; Clarke, G.C. The transformation of conifer forests in Britain-regeneration, gap size and silvicultural systems. For. Ecol. Manag. 2001, 151, 7-23. [CrossRef]

34. Nyland, R.D. Silviculture: Concepts and Applications; McGraw-Hill: New York, NY, USA, 2016.

35. Dey, D.C.; Brissette, J.C.; Schweitzer, C.J.; Guldin, J.M. Silviculture of forests in the eastern United States. In Cumulative Watershed Effects of Fuel Management in the Eastern United States; LaFayette, R., Brooks, M.T., Potyondy, J.P., Audin, L., Krieger, S.L., Trettin, C.C., Eds.; Gen. Tech. Rep. SRS-161; U.S. Department of Agriculture, Forest Service, Southern Research Station: Asheville, NC, USA, 2012; pp. 7-40.

36. Schmidt, W.C.; Shearer, R.C.; Roe, A.L. Ecology and Silviculture of Western Larch Forests; U.S. Department of Agriculture, Forest Service: Washington, DC, USA, 1976.

37. Seidel, K.W. Regeneration in Mixed Conifer and Douglas-Fir Shelterwood Cuttings in the Cascade Range of Washington; Res. Pap. RP-PNW-314; U.S. Department of Agriculture, Forest Service, Pacific: Portland, OR, USA, 1983.

38. Barnett, J.P.; Baker, J.B. Regeneration methods. In Forest Regeneration Manual; Duryea, M.L., Dougherty, P.M., Eds.; Springer: Dordrecht, The Netherlands, 1991; pp. 3-50.

39. Brockway, D.G.; Outcalt, K.W. Gap-phase regeneration in longleaf pine wiregrass ecosystems. For. Ecol. Manag. 1998, 106, 125-139. [CrossRef]

40. Voicu, M.F.; Comeau, P.G. Microclimatic and spruce growth gradients adjacent to young aspen stands. For. Ecol. Manag. 2006, 221, 13-26. [CrossRef]

41. Walters, M.B.; Farinos, E.J.; Willis, J.L.; Gottschalk, K.W. Managing for diversity: Harvest gap size drives complex light, vegetation, and deer herbivory impacts on tree seedlings. Ecosphere 2016, 7, e01397. [CrossRef] 
42. De Montigny, L.E.; Smith, N.J. The effects of gap size in a group selection silvicultural system on the growth response of young, planted Douglas-fir: A sector plot analysis. Forestry 2017, 90, 426-435. [CrossRef]

43. Flower, C.E.; Knight, K.S.; Gonzalez-Meler, M.A. Impacts of the emerald ash borer (Agrilus planipennis. Fairmaire) induced ash (Fraxinus spp.) mortality on forest carbon cycling and successional dynamics in the eastern United States. Biol. Invasions 2013, 15, 931-944. [CrossRef]

44. Keever, C. Present composition of some stands of the former oak-chestnut forest in the southern Blue Ridge Mountains. Ecology 1953, 34, 44-54. [CrossRef]

45. Ellison, A.M.; Bank, M.S.; Clinton, B.D.; Colburn, E.A.; Elliott, K.; Ford, C.R.; Foster, D.R.; Kloeppel, B.D.; Knoepp, J.D.; Lovett, G.M.; et al. Loss of foundation species: Consequences for the structure and dynamics of forested ecosystems. Front. Ecol. Environ. 2005, 3, 479-486. [CrossRef]

46. Hart, J.L.; van de Gevel, S.L.; Grissino-Mayer, H.D. Forest dynamics in a natural area of the southern Ridge and Valley, Tennessee. Nat. Areas J. 2008, 28, 275-289. [CrossRef]

47. van de Gevel, S.L.; Hart, J.L.; Spond, M.D.; White, P.B.; Sutton, M.N.; Grissino-Mayer, H.D. American chestnut to northern red oak: Forest dynamics in an old-growth forest in the Blue Ridge Mountains, USA. Botany 2012, 90, 126-1276. [CrossRef]

48. Axelson, J.N.; Alfaro, R.I.; Hawkes, B.C. Changes in stand structure in uneven-aged lodgepole pine stands impacted by mountain pine beetle epidemics and fires in central British Columbia. For. Chron. 2010, 87-99. [CrossRef]

49. Dordel, J.; Feller, M.C.; Simard, Z.W. Effects of mountain pine beetle (Dendroctonus ponderosae Hopkins) infestations on forest stand structure in southern Canadian Rocky Mountains. For. Ecol. Manag. 2008, 255, 3563-3570. [CrossRef]

50. Ocasio-Morales, R.G.; Tsopelas, P.; Harrington, T.C. Origin of Ceratocytis platani on native Platanus orientalis in Greece and its impact on natural forests. Plant Dis. 2007, 91, 901-904. [CrossRef]

51. Swetnam, T.W.; Lynch, A.M. A tree-ring reconstruction of western spruce budworm history in the southern Rocky Mountains. For. Sci. 1989, 35, 962-986.

52. Klooster, W.S.; Herms, D.A.; Knight, K.S.; Herms, C.P.; McCullough, D.G.; Smith, A.; Gandhi, K.J.K.; Cardina, J. Ash (Fraxinus spp.) mortality, regeneration, and seed bank dynamics in mixed hardwood forests following invasion by emerald ash borer (Agrilus planipennis). Biol. Invasions 2014, 16, 859-873. [CrossRef]

53. Kolka, R.K.; D'Amato, A.W.; Wagenbrenner, J.W.; Slesak, R.A.; Pypker, T.G.; Youngquist, M.B.; Grinde, A.R.; Palik, B.J. Review of ecosystem level impacts of emerald ash borer on black ash wetlands: What does the future hold? Forests 2018, 9, 179. [CrossRef]

54. Hancock, J.E.; Arthur, M.A.; Weathers, K.C.; Lovett, G.M. Carbon cycling along a gradient of beech bark disease impact in the Catskill Mountains, New York. Can. J. For. Res. 2008, 38, 1267-1274. [CrossRef]

55. Mueller, R.C.; Scudder, C.M.; Porter, M.E.; Trotter, R.T.; Gehring, C.A.; Whitman, T.G. Differential tree mortality in response to severe drought: Evidence for long-term vegetation shifts. J. Ecol. 2005, 93, 1085-1093. [CrossRef]

56. Elliot, K.J.; Swank, W.T. Impacts of drought on tree mortality and growth in a mixed hardwood forest. J. Veg. Sci. 1994, 5, 229-236. [CrossRef]

57. Cosgriff, R.J.; Nelson, J.C.; Yin, Y. Floodplain forest response to large-scale flood disturbance. Trans. Ill. State Acad. Sci. 2007, 100, 47-70.

58. Sakai, T.; Tanaka, H.; Shibata, M.; Suzuki, W.; Nomiya, H.; Kanazashi, T.; Iida, S.; Nakashizuka, T. Riparian disturbance and community structure of a Quercus-Ulmus forest in central Japan. Plant Ecol. 1999, 140, 99-109. [CrossRef]

59. Covey, K.R.; Barrett, A.L.; Ashton, M.S. Ice storms as a successional pathway for Fagus grandifolia advancement in Quercus rubra dominated forests of southern New England. Can. J. For. Res. 2015, 45, 1628-1635. [CrossRef]

60. Rebertus, A.J.; Shifley, S.R.; Richards, R.H.; Roovers, L.M. Ice storm damage to an old-growth oak-hickory forest in Missouri. Am. Midl. Nat. 1997, 137, 48-61. [CrossRef]

61. Turcotte, R.M.; Elliott, T.R.; Fajvan, M.A.; Park, Y.L.; Snider, D.A.; Tobin, P.C. Effects of ice storm damage on hardwood survival and growth in Ohio. North. J. Appl. For. 2012, 29, 53-59.

62. Lafon, C.W. Forest disturbance by ice storms in Quercus forests of the southern Appalachian Mountains. Ecoscience 2006, 13, 30-43. [CrossRef] 
63. Whitney, H.E.; Johnson, W.C. Ice storms and forest succession in southwestern Virginia. Bull. Torrey Bot. Club 1984, 111, 429-437. [CrossRef]

64. McIntosh, A.C.S.; Macdonald, S.E. Potential for lodgepole pine regeneration after mountain pine beetle attack in newly invaded Alberta stands. For. Ecol. Manag. 2013, 295, 11-19. [CrossRef]

65. Fajvan, M.A.; Wood, J.M. Stand structure and development after gypsy moth defoliation in the Appalachian Plateau. For. Ecol. Manag. 1996, 89, 79-88. [CrossRef]

66. Kayes, L.J.; Tinker, D.B. Forest structure and regeneration following a mountain pine beetle epidemic in southeastern Wyoming. For. Ecol. Manag. 2012, 263, 57-66. [CrossRef]

67. Seiwa, K.; Miwa, Y.; Akasaka, S.; Kanno, H.; Tomita, M.; Saitoh, T.; Ueno, N.; Kimura, M.; Hasegawa, Y.; Konno, M.; et al. Landslide-facilitated species diversity in a beech-dominated forest. Ecol. Res. 2013, 28, 29-41. [CrossRef]

68. Miles, D.W.R.; Swanson, F.J. Vegetation composition on recent landslides in the Cascade Mountains of western Oregon. Can. J. For. Res. 1986, 16, 739-744. [CrossRef]

69. Fulè, P.Z.; Course, J.E.; Heinlein, T.A.; Moore, M.M.; Covington, W.; Verkamp, G. Mixed-severity fire regime in a high-elevation forest of Grand Canyon, Arizona, USA. Landsc. Ecol. 2003, 18, 465-486. [CrossRef]

70. Taylor, A.H.; Skinner, C.N. Fire history and landscape dynamics in a late-successional reserve, Klamath Mountains, California, USA. For. Ecol. Manag. 1998, 111, 285-301. [CrossRef]

71. Lentile, L.B.; Smith, F.W.; Shepperd, W.D. Patch structure, fire-scar formation, and tree regeneration in a large mixed-severity fire in the South Dakota Black Hills, USA. Can. J. For. Res. 2005, 35, 2875-2885. [CrossRef]

72. Mortenson, L.A.; Hughes, R.F.; Friday, J.B.; Keith, L.M.; Barbosa, J.M.; Friday, N.J.; Liu, Z.; Sowards, T.G. Assessing spatial distribution, stand impacts and rate of Ceratocystis fimbriata induced 'ōhi'a (Metrosideros polymorpha) mortality in tropical wet forest, Hawai'I.; Island, USA. For. Ecol. Manag. 2016, 377, 83-92. [CrossRef]

73. Cox, L.E.; Hart, J.L.; Dey, D.C.; Schweitzer, C.J. Composition, structure, and intra-stand spatial patterns along a disturbance severity gradient in a Quercus stand. For. Ecol. Manag. 2016, 381, 305-317. [CrossRef]

74. Holzmueller, E.J.; Gibons, D.J.; Suchecki, P.F. Accelerated succession following an intense wind storm in an oak-dominated forest. For. Ecol. Manag. 2012, 279, 141-146. [CrossRef]

75. Altman, J.; Dolezal, J.; Cerny, T.; Song, J.S. Forest response to increasing typhoon activity on the Korean peninsula: Evidence from oak tree-rings. Glob. Chang. Biol. 2013, 19, 498-504. [CrossRef] [PubMed]

76. Myster, R.W.; Malahy, M.P. Tornado effects on damage, resprouting and spatial heterogeneity in the Cross Timbers ecotone of Oklahoma, USA. J. Plant Ecol. 2010, 3, 157-163. [CrossRef]

77. Nagel, T.A.; Diaci, J. Intermediate wind disturbance in an old-growth beech-fir forest in southeastern Slovenia. Can. J. For. Res. 2006, 36, 629-638. [CrossRef]

78. Peterson, C.J. Consistent influence of tree diameter and species on damage in nine eastern North America tornado blowdowns. For. Ecol. Manag. 2007, 250, 96-108. [CrossRef]

79. Peterson, C.J.; Rebertus, A.J. Tornado damage and initial recovery in three adjacent, lowland temperate forests in Missouri. J. Veg. Sci. 1997, 8, 559-564. [CrossRef]

80. Woods, K.D. Intermediate disturbance in a late-successional hemlock-northern hardwood forest. J. Ecol. 2004, 92, 464-476. [CrossRef]

81. Nagel, T.A.; Svoboda, M.; Diaci, J. Regeneration patterns after intermediate wind disturbance in an old-growth Fagus-Abies forest in southeastern Slovenia. For. Ecol. Manag. 2006, 226, 268-278. [CrossRef]

82. Shankman, D. Channel migration and vegetation patterns in the southeastern Coastal Plain. Conserv. Biol. 1993, 7, 176-183. [CrossRef]

83. Lafon, C.W. Ice storms in central hardwood forests: The disturbance regime, spatial patterns, and vegetation influences. In Natural Disturbances and Historic Range of Variation: Type, Frequency, Severity, and Post-Disturbance Structure in Central Hardwood Forests USA; Greenberg, C.H., Collins, B.S., Eds.; Springer International Publishing: Cham, Switzerland, 2016; pp. 147-166.

84. Agee, J.K. The landscape ecology of Western forest fire regimes. Northwest Sci. 1998, 72, 24-34.

85. Arno, S.F.; Parsons, D.J.; Keane, R.E. Mixed-severity fire regimes in the northern Rocky Mountains: Consequences of fire exclusion and options for the future. In Wilderness Science in a Time of Change Conference; U.S. Department of Agriculture Forest Service, Rocky Mountain Research Station: Ogden, UT, USA, 2000; pp. 225-232. 
86. Heyerdahl, E.K.; Loehman, R.A.; Falk, D.A. Mixed-severity fire in lodgepole pine dominated forests: Are historical regimes sustainable on Oregon's Pumice Plateau, USA? Can. J. For. Res. 2014, 44, 593-603. [CrossRef]

87. Mark, A.F.; Scott, G.A.M.; Sanderson, F.R.; James, P.W. Forest succession on landslides above Lake Thomson, Fiordland. N. Z. J. Bot. 1964, 2, 60-89. [CrossRef]

88. Wooten, R.M.; Witt, A.C.; Miniat, C.F.; Hales, T.C.; Aldred, J.L. Frequency and magnitude of historical selected landslide events in the southern Appalachian Highlands of North Carolina and Virginia: Relationships to rainfall, geological, and ecohydrological controls, and effects. In Natural Disturbances and Historic Range of Variation: Type, Frequency, Severity, and Post-Disturbance Structure in Central Hardwood Forests USA; Greenberg, C.H., Collins, B.S., Eds.; Springer International Publishing: Cham, Switzerland, 2016; pp. 203-262.

89. Buma, B. Disturbance interactions: Characterization, prediction, and the potential for cascading effects. Ecosphere 2015, 6, 70. [CrossRef]

90. Harvey, B.J.; Donata, D.C.; Romme, W.H.; Turner, M.G. Influence of recent bark beetle outbreak on fire severity and postfire tree regeneration in montane Douglas-fir forests. Ecology 2013, 94, 2475-2486. [CrossRef] [PubMed]

91. Agne, M.C.; Shaw, D.C.; Woolley, T.J.; Queijeiro-Bolanõs, M.E. Effects of dwarf mistletoe on stand structure of lodgepole pine forests 21-28 years post-mountain pine beetle epidemic in central Oregon. PLoS ONE 2014, 9, e107532. [CrossRef] [PubMed]

92. Hart, J.L.; Cox, L.E. Incorporating intermediate-severity disturbances in oak stand development. Forests 2017, 8, 284. [CrossRef]

93. Peterson, C.J.; Cannon, J.B.; Godfrey, C.M. First steps in defining the wind disturbance regime in central hardwood forests. In Natural Disturbances and Historic Range of Variation: Type, Frequency, Severity, and Post-Disturbance Structure in Central Hardwood Forests USA; Greenberg, C.H., Collins, B.S., Eds.; Springer International Publishing: Cham, Switzerland, 2016; pp. 89-122.

94. Nowacki, G.J.; Abrams, M.D. Radial-growth averaging criteria for reconstructing disturbance histories from presettlement-origin oaks. Ecol. Monogr. 1997, 67, 225-249. [CrossRef]

95. Ruffner, C.M.; Abrams, M.D. Relating land-use history and climate to the dendroecology of a 326-year old Quercus prinus talus slope forest. Can. J. For. Res. 1998, 28, 347-358. [CrossRef]

96. Lafon, C.W.; Speer, J.H. Using dendrochronology to identify major ice storm events in oak forests of southwestern Virginia. Clim. Res. 2002, 20, 41-54. [CrossRef]

97. Hart, J.L.; Grissino-Mayer, H.D. Vegetation patterns and dendroecology of a mixed hardwood forest on the Cumberland Plateau: Implications for stand development. For. Ecol. Manag. 2008, 255, 1960-1975. [CrossRef]

98. Hart, J.L.; Clark, S.L.; Torreano, S.J.; Buchanan, M.L. Composition, structure, and dendroecology of an old-growth Quercus forest on the tablelands of the Cumberland Plateau, USA. For. Ecol. Manag. 2012, 266, 11-24. [CrossRef]

99. Hart, J.L.; Cowden, M.M.; Torreano, S.J.; Vestal, P.R. Disturbance, succession, and structural development of an upland hardwood forest on the Interior Low Plateau, Tennessee. Nat. Areas J. 2015, 35, 557-573. [CrossRef]

100. Ford, S.A.; Kleinman, J.S.; Hart, J.L. Spatial patterns of canopy disturbance, structure, and species composition in a multi-cohort hardwood stand. Forests 2017, 8, 93. [CrossRef]

101. Zielonka, T.; Holeksa, J.; Fleischer, P.; Kapusta, P. A tree-ring reconstruction of wind disturbances in a forest of the Slovakian Tatra Mountains, Western Carpathians. J. Veg. Sci. 2010, 21, 31-42. [CrossRef]

102. Svoboda, M.; Janda, P.; Nagel, T.A.; Fraver, S.; Rejzek, J.; Bače, R. Disturbance history of an old-growth sub-alpine Picea abies stand in the Bohemian Forest, Czech Republic. J. Veg. Sci. 2012, 23, 86-97. [CrossRef]

103. Splechtna, B.E.; Georg, G.; Black, B.A. Disturbance history of a European old-growth mixed-species forest-A spatial dendro-ecological analysis. J. Veg. Sci. 2005, 16, 511-522.

104. Nagel, T.A.; Levanic, T.; Diaci, J. A dendroecological reconstruction of disturbance in an old-growth Fagus-Abies forest in Slovenia. Ann. For. Sci. 2007, 64, 891-897. [CrossRef]

105. Trotsiuk, V.; Hobi, M.L.; Commarmot, B. Age structure and disturbance dynamics of the relic virgin beech forest Uholka (Ukrainian Carpathians). For. Ecol. Manag. 2012, 265, 181-190. [CrossRef]

106. Abrams, M.D.; van de Gevel, S.L.; Dodson, R.C.; Copenheaver, C.A. The dendroecology and climatic impacts for old-growth white pine and hemlock on the extreme slopes of the Berkshire Hills, Massachusetts, USA. Can. J. Bot. 2000, 78, 851-861. 
107. Axelson, J.N.; Alfaro, R.I.; Hawkes, B.C. Influence of fire and mountain pine beetle on the dynamics of lodgepole pine stands in British Columbia, Canada. For. Ecol. Manag. 2009, 257, 1874-1882. [CrossRef]

108. Fraver, S.; Seymour, R.S.; Speer, J.H.; White, A.S. Dendrochronological reconstruction of spruce budworm outbreaks in northern Maine, USA. Can. J. For. Res. 2007, 37, 523-529. [CrossRef]

109. Boulanger, Y.; Arseneault, D.; Morin, H.; Jardon, Y.; Bertrand, P.; Dagneau, C. Dendrochronological reconstruction of spurce budworm (Choristoneura fumiferana) outbreaks in southern Quebec for the last 400 years. Can. J. For. Res. 2012, 42, 1264-1276. [CrossRef]

110. Baker, P.J.; Bunyavejchewin, S.; Oliver, C.D.; Ashton, P.S. Disturbance history and historical stand dynamics of a seasonal tropical forest in western Thailand. Ecol. Monogr. 2005, 75, 317-343. [CrossRef]

111. D'Amato, A.W.; Jokela, E.J.; O'Hara, K.L.; Long, J.N. Silviculture in the United States: An amazing period of change over the past 30 years. J. For. 2018, 116, 55-67. [CrossRef]

112. Franklin, J.F.; Spies, T.A.; Van Pelt, R.; Carey, A.B.; Thornburgh, D.A.; Berg, D.R.; Lindenmayer, D.B.; Harmon, M.E.; Keeton, W.S.; Shaw, D.C.; et al. Disturbances and structural development of natural forest ecosystems with silvicultural implications, using Douglas-fir forests as an example. For. Ecol. Manag. 2002, 155, 399-423. [CrossRef]

113. Long, J.N. Emulating natural disturbance regimes as a basis for forest management: A North American view. For. Ecol. Manag. 2009, 257, 1868-1873. [CrossRef]

114. Buma, B.; Wessman, C.A. Differential species responses to compounded perturbations and implications for landscape heterogeneity and resilience. For. Ecol. Manag. 2012, 266, 25-33. [CrossRef]

115. Reyer, C.P.O.; Rammig, A.; Brouwers, N.; Langerwisch, F. Forest resilience, tipping points and global change processes. J. Ecol. 2015, 103, 1-4. [CrossRef]

116. Trumbore, S.; Brando, P.; Hartmann, H. Forest health and global change. Science 2015, 349, $814-818$. [CrossRef] [PubMed]

117. DeRose, R.J.; Long, J.N. Resistance and resilience: A conceptual framework for silviculture. For. Sci. 2014, 60, 1205-1212. [CrossRef]

118. Seidl, R.; Rammer, W.; Spies, T.A. Disturbance legacies increase the resilience of forest ecosystem structure, composition, and functioning. Ecol. Appl. 2014, 24, 2063-2077. [CrossRef] [PubMed]

119. Cantarello, E.; Newton, A.C.; Martin, P.A.; Evans, P.M.; Gosal, A.; Lucash, M.S. Quantifying resilience of multiple ecosystem services and biodiversity in a temperate forest landscape. Ecol. Evol. 2017, 7, 9661-9675. [CrossRef] [PubMed]

120. Donato, D.C.; Campbell, J.L.; Franklin, J.F. Multiple successional pathways and precocity in forest development: Can some forests be born complex? J. Veg. Sci. 2012, 23, 576-584. [CrossRef]

121. Meigs, G.; Keeton, W.S. Intermediate-severity wind disturbance in mature temperate forests: Legacy structure, carbon storage, and stand dynamics. Ecol. Appl. 2018, 28, 798-815. [CrossRef] [PubMed]

122. Axelson, J.N.; Hawkes, B.C.; van Akker, L.; Alfaro, R.I. Stand dynamics and the mountain pine beetle-Thirty years of forest change in Waterton Lakes National Park, Alberta, Canada. Can. J. For. Res. 2018. [CrossRef]

123. O'Hara, K.L. Multiaged Silviculture: Managing for Complex Forest Stand Structures; Oxford University Press: Oxford, UK, 2014.

124. O'Hara, K.L.; Ramage, B.S. Silviculture in an uncertain world: Utilizing multi-aged management systems to integrate disturbance. Forestry 2013, 86, 401-410. [CrossRef]

125. Mitchell, S.J.; Beese, W.J. The retention system: Reconciling variable retention with the principles of silvicultural systems. For. Chron. 2002, 78, 397-403. [CrossRef]

126. Seymour, R.S. Integrating disturbance parameters into conventional silvicultural systems: Experience from the Acadian forest of northeastern North America. In Balancing Ecosystem Values: Innovative Experiments for Sustainable Forestry; Peterson, C.E., Maguire, D.A., Eds.; U.S. Department of Agriculture Forest Service: Washington, DC, USA, 2005; pp. 41-48.

127. Raymond, P.; Bèdard, S.; Roy, V.; Larouche, C.; Tremblay, S. The irregular shelterwood system: Review, classification, and potential application to forests affected by partial disturbances. J. For. 2009, 107, 405-413. [CrossRef]

128. Beese, W.J.; Dunsworth, B.G.; Zielke, K.; Bancroft, B. Maintaining attributes of old-growth forests in coastal BC through variable retention. For. Chron. 2003, 79, 570-578. [CrossRef]

129. O'Hara, K.L.; Nagel, L.M. The stand: Revisiting a central concept in forestry. J. For. 2013, 111, 335-340. [CrossRef] 
130. Franklin, J.F.; Mitchell, R.J.; Palik, B.J. Natural Disturbance and Stand Development Principles for Ecological Forestry; GTR-NRS-19; U.S. Department of Agriculture Forest Service: Newton Square, PA, USA, 2007; p. 44.

131. Bradford, J.B.; Betancourt, J.L.; Butterfield, B.J.; Munson, S.M.; Wood, T.E. Anticipatory natural resource science and management for a changing futurE. Front. Ecol. Environ. 2018, 16, 295-303. [CrossRef] 